\title{
Implications of Urbanization on Housing Condition in Gwagwalada Town, Abuja, Nigeria
}

\author{
Waheeda Ahmed Belel ${ }^{1}$, Zaheeda Ahmed Belel ${ }^{1}$, Zaynab Belel Ahmad², \\ Mahmoud Hijab Abubakar ${ }^{2, *}$
}

\author{
${ }^{1}$ Chardie Engineering Services, 13/14 Falu Road, Masakare, Jimeta - Yola, 640101, Nigeria \\ ${ }^{2}$ Civil Engineering Department, Modibbo Adama University of technology, Yola., Nigeria \\ *Corresponding Author
}

DOI: https://doi.org/10.30880/jtmb.2019.06.02.003

Received 31 October 2018; Accepted 07 May 2019; Available online 30 June 2019

\begin{abstract}
There is massive movement from the rural to urban areas; leading to shortages in housing and social amenities. This paper, therefore, examines the implications of urbanization on housing condition in Gwagwalada town. The objectives of the study are to find out the factors that lead to urbanization, the housing conditions in the study and the effects of rapid population growth on housing condition. Descriptive statistics and ranking method were employed to resolve these objectives. Questionnaires were distributed in three wards of the study area. A sample size of 100 responded was selected using the Taro Yamane's formula. The research findings show that upsurge population growth is caused by migration; the population growth affects the quality, quantity and environmental facilities of housing. The research recommended that if urbanization is properly managed, will bring about economic and social development. Also planning backed by reliable data should be embarked in order to tackle the growth in formal settlements.
\end{abstract}

Keywords: Housing condition, Urbanization, population, facilities, growth.

\section{Introduction}

The urbanization process is accompanied by an increasing migration of people to cities in the world generally. The driving force for this action is commonly associated with the search for better prospects of employment, a better living standard and accessibility to an enhanced basic human services [1, 2]. Urbanization, especially rapid urbanization is always accompanied by numerous challenges and opportunities. It facilitates the creation of job's opening and markets for rural products, it accelerates variation in settlement conditions and transforms everyday life by rearranging existing social order and introducing new social configuration, lifestyle pattern, values, attitudes and behavior [3,4].

Urbanization is a global phenomenon sweeping through most cities like a wild fire [5]. As a result of the magnitude and speed, it exerts demand on urban facilities which leads to poor housing development condition. The population of urban centers is increasing by the day and housing is not keeping pace with the rising population [6].

Early urbanization was attributed to push and pull factors of rural-urban migration. Early migrants, usually males went to the city in search of jobs and better life. Even in modern times, the lure of the cities and opportunities it offers continue to be a driving force of urbanization in many cities and towns [7]. Most people move into urban areas because they are pushed out by factors such as poverty, environmental degradation, food insecurity and lack of basic infrastructures and services in the rural areas. They are pulled into urban centers by 
advantages and opportunities of the cities including water supply, electricity and education [5, 8].

Over the years, it has been recognized that urban growth is attributable to natural growth . According to Thomas [9], research indicates that natural increase can be responsible for about $60 \%$ of urban population growth in some developing countries. While acknowledging that urban populations are still growing, in most cases rapidly, Potts [10], concurs that such growth is largely attributed to natural increase as birth rate exceeds death rate in towns. On contrary, Thomas [9], argues that because rates of natural increase are generally slightly lower in urban areas than in rural areas, the principal reason for rising levels of urbanization is rural-urban migration.

A house could be described as a dwelling unit, it is more than a shelter as it includes physical structures as well as surrounding environments [11]. Housing is described as a unit of a house, its immediate environment, sanitation, drainage, residential facilities and all economic and social activities that makes life worthwhile [5, 11]. Most contemporary African cities are characterized by poor housing, water, sanitation and health infrastructures [12]. Makinde [13], identified housing problem as economic recession which hinders housing supply; inaccessibility of land, high cost of building and construction materials, high planning standard by planning authorities and delay in plan approval. Omole [14], classified housing problems into; qualitative housing problem which is the inability of a dweller to get satisfaction regarding certain minimal safety and environmental facilities such as water supply, access road, electricity, telecommunication facilities as well as social infrastructure such as hospitals, clinics, school and markets and quantitative housing problem which is the absolute shortage of dwelling unit or insufficient supply of housing compared to total demand [15, 16]. Folaranmi [17], concurs that the important criteria in assessment of housing condition comprise;

1) The nature of lighting, air spaces and open spaces.

2) Indoor and environmental sanitation.

3) Availability of toilets, bathrooms, water, electricity.

4) Types of building material used.

5) Building orientation and level of ventilation.

6) Drainage and general environmental condition

\section{Effects of urbanization on housing}

Owing to rapid urbanization, access to land for housing development has become almost an insurmountable challenge. In recent years, the prices of land have risen exponentially, making it difficult for low and middle income earners, the situation has aggravated by multiple complex system of land tenure in cities and town [9].

Overcrowding is logical consequence of overpopulation in urban areas. Adekola [18], asserted that it is naturally expected that cities and towns that have large number of population squeezed in small space suffer from overcrowding. This problem is specifically more acute in urban areas where there is large influx of unemployed and underemployed immigrants who have no place to live in.

Water supply problem is a major challenge in most developing countries. A stage has been reached where practically most cities gets insufficient water to meet the needs of the city households. Most individual town require large water quantities and majority of towns and cities do not get recommended quantities of water. Most of the cities and small towns have no main water supply at all and depend on such sources as individual tube wells, household open wells or even river [19].

As cities and towns grow in number and size, the problem of waste disposal is assuming alarming proportions; huge quantities of garbage disposals and the existing landfill are fill of brim. These landfills are hotbeds of diseases and numerous poisons leaking into the surroundings of households and below contaminating ground water. People who live in nearby areas have to endure smells of rotten garbage and also fall victims of diseases like malaria, typhoid, plague, dysentery [20]. Most towns and cities are also almost invariably plagued with insufficient sewerage facilities that have old sewerage lines which are not properly maintained. These often break down or over flow inadvertently drain into water bodies, and consequently pollution occurs [21].

\section{Study area}

The article examined three main township wards, Gwagwalada Central Ward, Quarter's Ward and Kutunku Ward (see fig. 1). It is located between latitude $8015^{\prime} \mathrm{N} 0$ and $900^{\prime} \mathrm{N}$ and Longitude $7000^{\prime} \mathrm{E}$ and 7 005' E. The tribes inhabiting the area are heterogeneous in nature, consisting of the original settlers of the town; the Bassa, the Gbagyi, others include the TIV, Hausa, Yoruba and Igbo. According to the National population commission (2006) report [22], Gwagwalada Area Council is having a population size of 15, 7770 of which $25 \%$ are township population and that is about 39,442 people. 


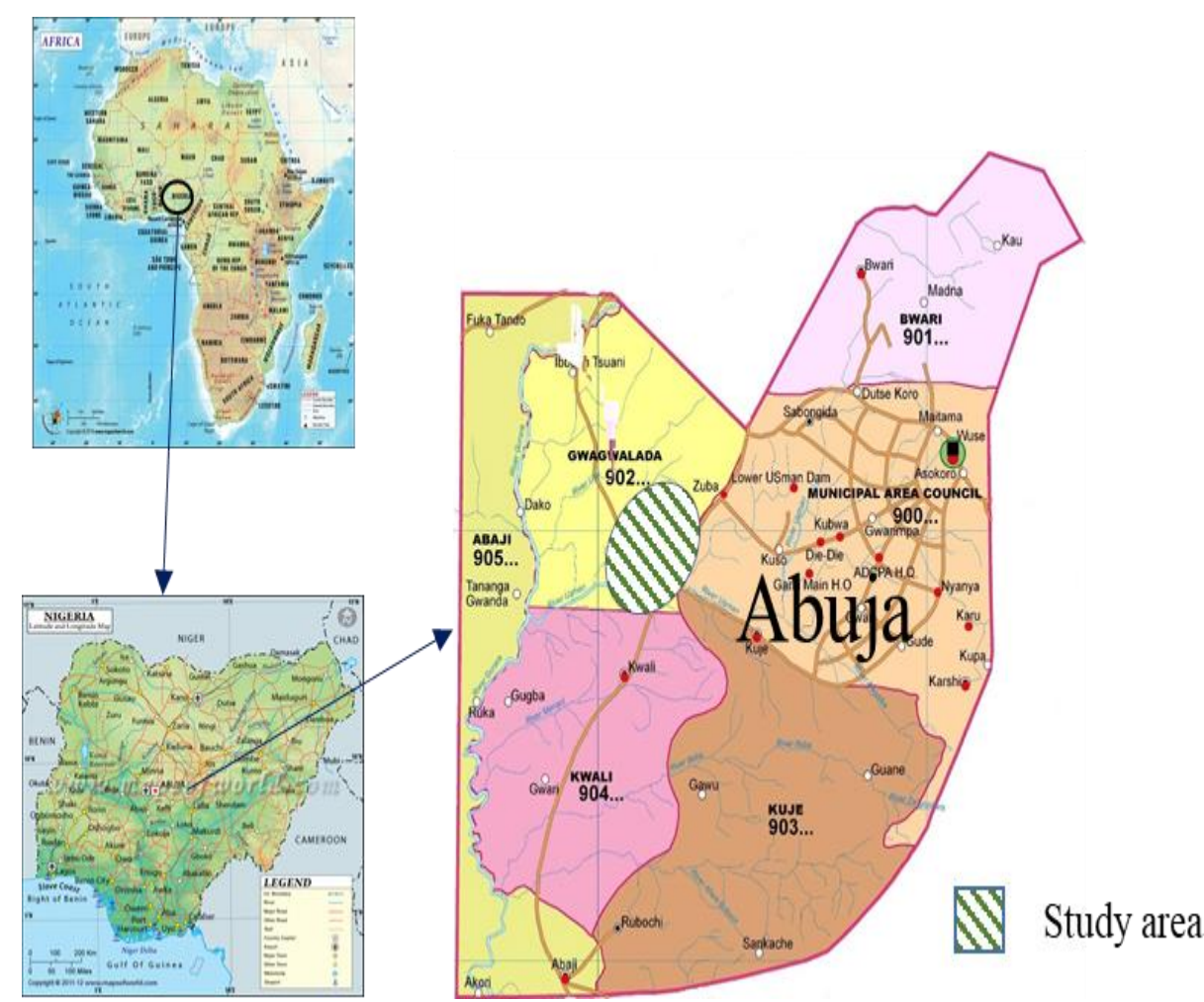

Fig. 1- Map of the study area

\section{Methodology}

The data collected for the study ware gathered using a detailed and self-administered questionnaire from sample residents in the study area. The research work considered Gwagwalada central, Quarters and Kutunku ward which were purposely selected because most initial development in Gwagwalada Town are based in the three wards and common to them is that the houses have dilapidated over time. A sample size of 100 questionnaires was administered. The sample size was determined using the Taro Yamane's formula $(n=N / 1+$ $N\left(e^{2}\right)$ ). Statistical techniques such as ranking method and measures of central tendency such as frequency and percentage were used for the analysis. Ranking method was used in rating the responses given to each risk factor. The responded were requested to indicate the severity of each risk on a five scale to measure a range of opinions with 1,2,3,4 and 5 as least severe, low severe, averagely severe, more severe and most severe respectively.

The total score was obtained by multiplying the number of respondents by the corresponding score mark and adding the results together.

Mean of each factor $=$ total score $/$ sample size

Relative Index = total score $/(($ highest score mark) $x$ (sample size $))$.

\section{Data presentation and analysis}

Figure 1 portrays that a reasonable proportion of the respondents are non-indigenes of Gwagwalada town and only $32.2 \%$ are indigenes of the study area. Quarters was the least occupied by non-indigenes. This signifies that urbanization is at its peak and most of the respondent are migrants. It also signifies that the cause of urbanization is mostly migration not natural increase in the study area. 


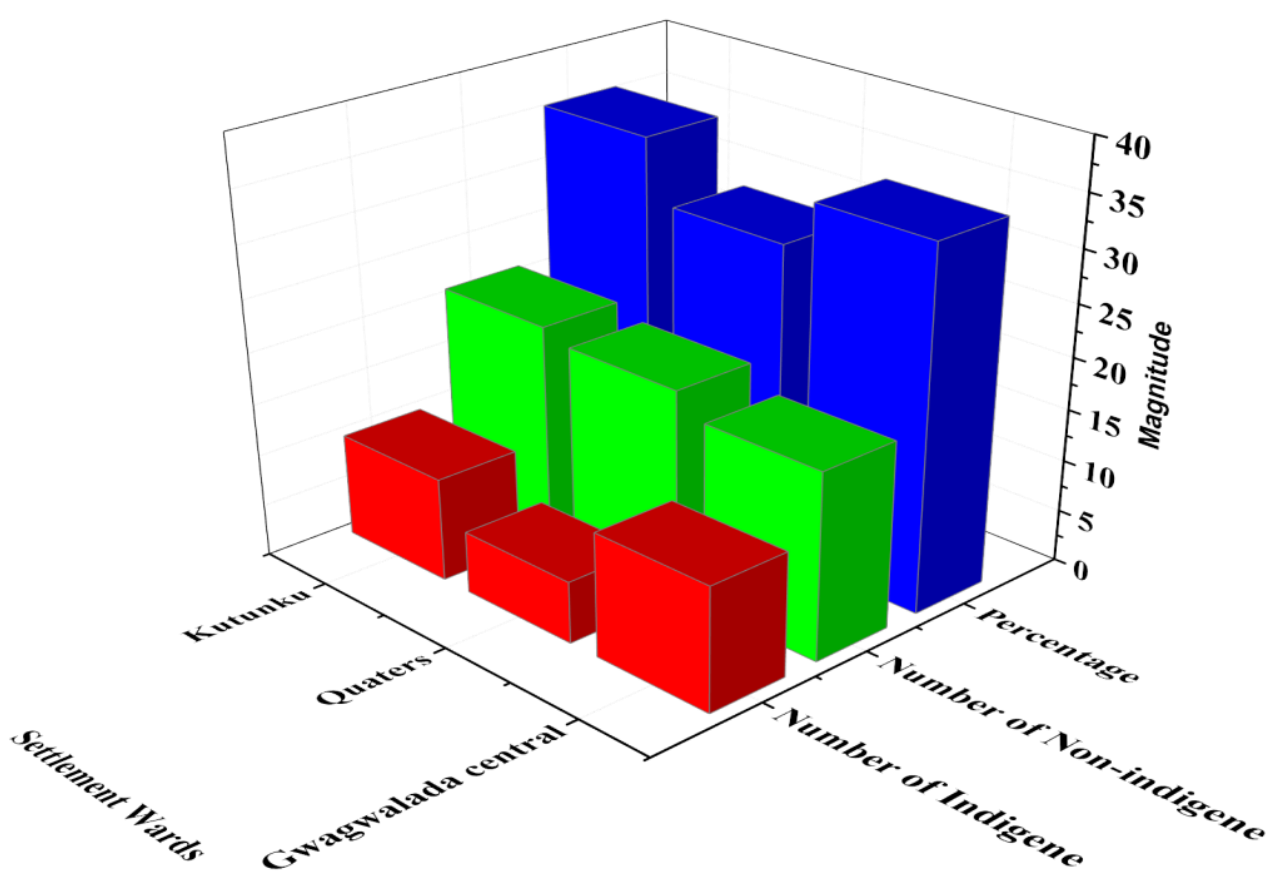

Fig. 1- Indigenous status of respondents

Figure 2 shows the reasons for migrating by respondents. 23\% migrated to the study area for job opportunity, $49.4 \%$ had migrated for educational purposes, while $20.7 \%$ of the respondents migrated to the study area as a result of marriage circumstances.

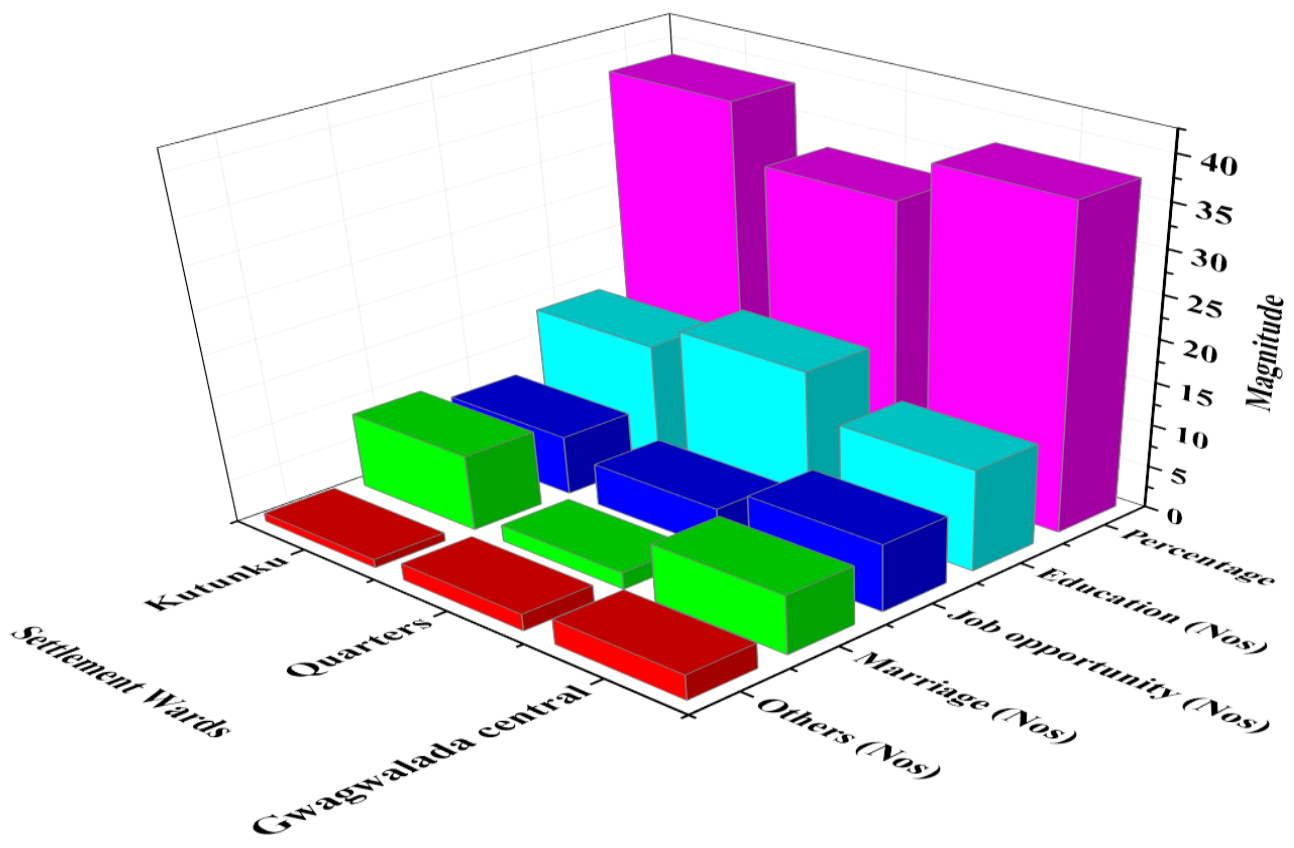

Fig. 2- Reasons for migration

The results here show that education and job opportunity are the major pull factors in the Gwagwalada town's migration.

Figure 3 depicts $24.1 \%$ of the respondents have $2-4$ households in their homes, $37.9 \%$ of the respondents indicated that 4-8 households live in their homes, $26.4 \%$ reported to have 8-12 households in a house while $11.5 \%$ reported to have 12 households and above. Based on the data quarters had the least ownership. This reveals that most of the respondents live in too little space which shows the effect of overcrowding. 


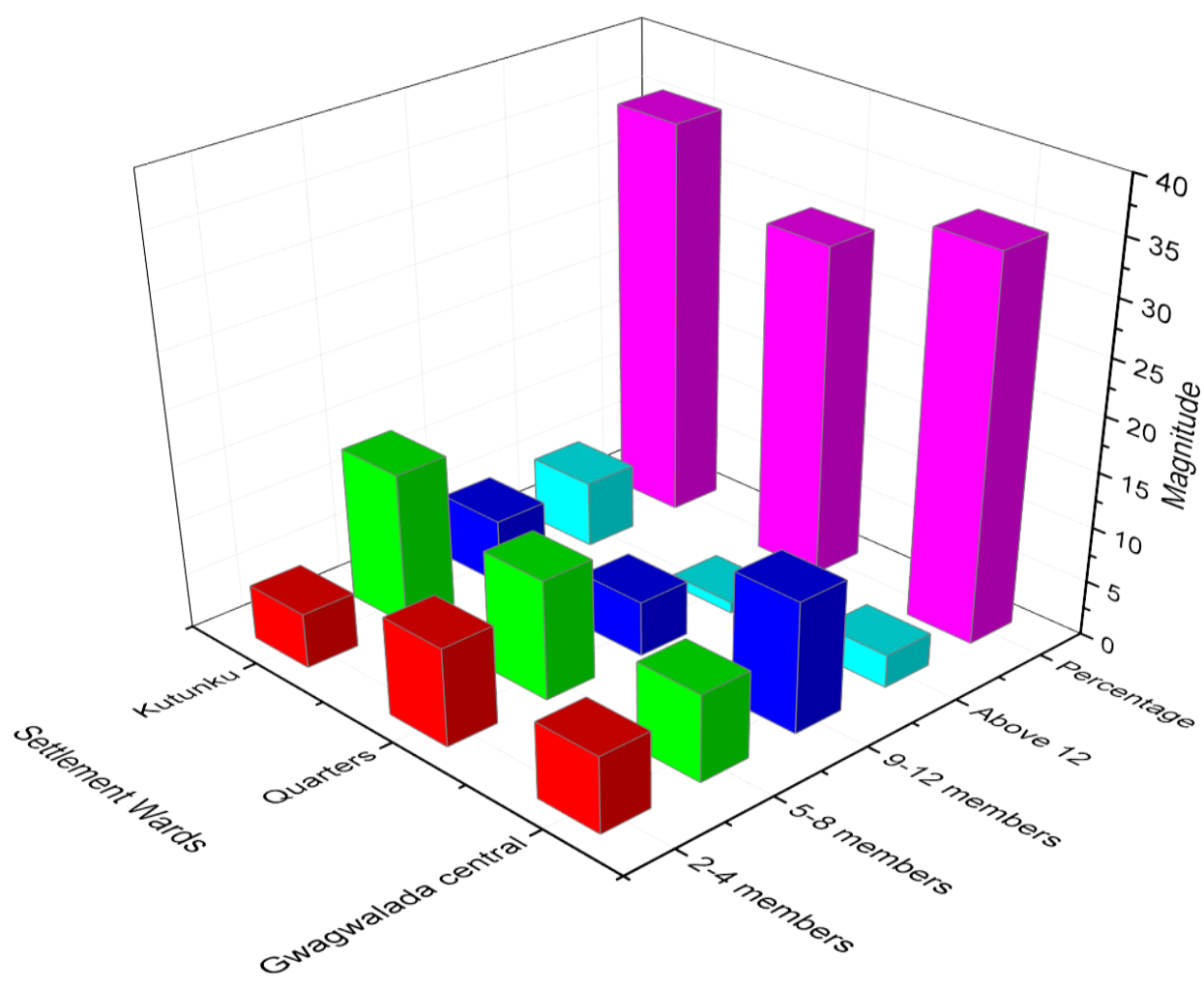

Fig. 3- Households ownership of respondents

Housing quality parameters were identified in the course of this research work. Figure 4 shows the availabilities of these facilities in and around the houses in the study area.

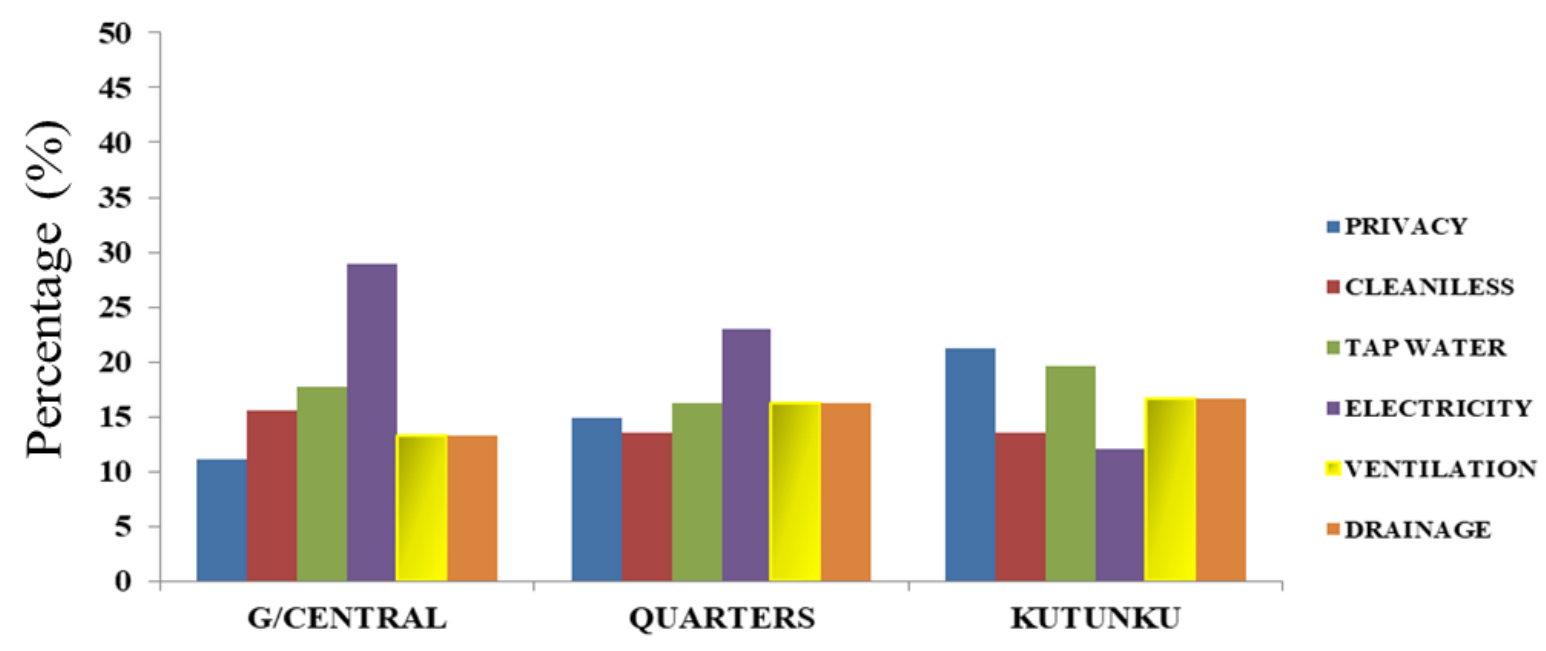

Fig. 4- Availability of housing amenities at dwelling units.

Many of the respondents indicated that there is inadequate privacy and ventilation in the study area especially at Gwagwalada area. Most of the amenities were below average. Gwagwalada area had higher reported (29.1\%) cases for adequate electricity supply followed by Quarters and Kutunku. Privacy was ranked higher at Kutunku than other parts of the study area, this may be attributed to the non- availability of the amenities hence less populated. Kutunku also exhibit a problem of poor drainage system and electricity supply in the area investigated.

Ranking of the responses in Table 1 indicates that overcrowding is the main effect of urbanization on housing condition in Gwagwalada. The respondents ranked growth of slumps and squatter settlement, and water 
supply problem as the 2nd and 3rd major effects of urbanization on the housing condition of the study area.

Table 1- Ranking effects of urbanization on housing condition in the study area

\begin{tabular}{|c|c|c|c|c|c|c|c|c|c|}
\hline \multirow{2}{*}{ Variable } & \multicolumn{5}{|c|}{ Response/ Scores } & \multirow{2}{*}{ Total } & \multirow{2}{*}{ Mean } & \multirow{2}{*}{ R.I } & \multirow{2}{*}{ Rank } \\
\hline & 1 & 2 & 3 & 4 & 5 & & & & \\
\hline Growth of slums \& squatter settlement & 9 & 10 & 21 & 7 & 40 & 320 & 3.68 & 0.74 & 2 \\
\hline Difficulties associated with land supply & 21 & 14 & 25 & 16 & 11 & 243 & 2.79 & 0.56 & 6 \\
\hline Overcrowding & 12 & 5 & 20 & 11 & 40 & 326 & 3.75 & 0.75 & 1 \\
\hline Water supply problem & 10 & 7 & 17 & 30 & 23 & 310 & 3.56 & 0.71 & 3 \\
\hline Waste disposal problem & 14 & 17 & 11 & 19 & 26 & 287 & 3.29 & 0.66 & 4 \\
\hline Sewerage problem & 8 & 19 & 22 & 15 & 19 & 267 & 3.07 & 0.61 & 5 \\
\hline
\end{tabular}

\section{Conclusions}

The research work assessed the implication of urbanization on housing condition in Gwagwalada Town. The result obtained shows that the major causes of urbanization in the study area is migration due to influx of people for better prospects of life such as education and job opportunities. The influx of the population has in turn led housing problems such as overcrowding, growth of slums and squatters, water supply and waste disposal problem. However, these problems can be minimized if planning is proactive and backed by reliable data. More houses for civil servant and workers should be provided so as to reduce current stress on existing facilities.

Government should facilitate the provision of basic social amenities in terms of water supply, waste management, electricity, proper drainage system and also promote rehabilitation and timely maintenance of these amenities. All causes of rural-urban migration should be looked into by the government and see that they are resolved. If the situation could be abated and reversed, it will remove pressures on urban resources. Urban areas will be depopulated and the visible and obvious consequences will be reduced.

\section{References}

Mueller V., Doss C., and Quisumbing A. (2018). Youth migration and labour constraints in African agrarian households. The Journal of Development Studies, vol. 54, no. 5, pp. 875-894.

Chitongo L., (2017). Public private partnerships and housing provision in Zimbabwe: the case of Runyararo south west housing scheme (mbudzi) masvingo. EuropeanJournal of Research in Social Sciences Vol, vol. 5, no. 4.

Cobbinah P.B., Erdiaw-Kwasie M.O. and Amoateng P. (2015). Africa's urbanisation: Implications for sustainable development, Cities, The International Journal of Urban Policy and Planning vol. 47, pp. 62-72.

Drakakis-Smith D., (2012). Urbanisation, housing and the development process, Routledge.

Opoko P.A. and Oluwatayo A.A., (2014). Trends in urbanisation: implication for planning and low-income housing delivery in Lagos, Nigeria, Architecture Research, vol. 4, no. 1, pp. 15-26.

Yakubu I., Akaateba M.A., and Akanbang B.A. (2014). A study of housing conditions and characteristics in the Tamale Metropolitan Area, Ghana, Habitat International, vol. 44, pp. 394-402.

Ozden K. and Enwere C. (2012). Urbanization and its political challenges in developing countries, Eurasian Journal of Business and Economics, vol. 5, pp. 99-120.

Gong P., Liang S., Carlton E.J., Jiang Q., Wu J., Wang L., and Remais J.V. (2012). Urbanisation and health in China., The Lancet, vol. 379, no. 9818, pp. 843-852.

Thomas S. (2008). Urbanization as a driver of change, Arup Journal, vol. 43, no. 1, p. 58. 
Potts D. (2012). Whatever Happened to Africa's Rapid Urbanisation?, World Economics, vol. 13, no. 2, pp. 17-30.

Jiboye A.D. (2014). Significance of house-type as a determinant of residential quality in Osogbo, Southwest Nigeria, Frontiers of Architectural Research, vol. 3, no. 1, pp. 20-27.

Adeoye D.O. (2016). Challenges of urban housing quality: Insights and experiences of Akure, Nigeria, Procedia Social and Behavioral Sciences, vol. 216, pp. 260-268.

Makinde O.O. (2014). Housing delivery system, need and demand, Environment, development and sustainability, vol. 16, no. 1, pp. 49-69.

Omole K.F. (2010). An assessment of housing condition and socio-economic life styles of slum dwellers in Akure, Nigeria, Contemporary Management Research, vol. 6, no. 4.

Makinde O.O. (2014). Housing delivery system, need and demand, Environment, development and sustainability, vol. 16, no. 1, pp. 49-69.

Kamruzzaman M. and Hakim M.A. (2016). Socio-economic status of slum dwellers: an empirical study on the capital city of Bangladesh, American Journal of Business and Society, vol. 1, no. 2, pp. 13-18.

Folaranmi A.O. (2012). Mass housing in Nigeria, customize the brief: provide a desired house, Journal of Civil and Environmental Research, vol. 2, no. 4, pp. 88-97.

Adekola P.O. (2016). Migration, urbanisation and environmental problems in Nigeria.

El-Hussain A.M. (2018). Factors of Spontaneous Physical Housing changes in Urban Centres of South West Nigeria , Architecture Research Journal, vol. 8, no. 2, pp. 74-85.

Adamkiewicz G., Spengler J.D., Harley A.E., Stoddard A., Yang M., Alvarez-Reeves M., and Sorensen G. (2014). Environmental conditions in low-income urban housing: clustering and associations with selfreported health, American journal of public health, vol. 104, no. 9, pp. 1650-1656.

Amis P. and Lloyd P., (2018). Housing Africa’s urban poor. Routledge.

National Population Commission. (2014). Report of Nigeria's National Population Commission on the 2006 Census. 